\title{
Long Non-Coding RNA Emergence During Renal Cell Carcinoma Tumorigenesis
}

\author{
Xiaobing Liu ${ }^{a}$ Yaxing Hao ${ }^{b}$ Wei Yu ${ }^{a}$ Xia Yang ${ }^{b}$ Xing Luo Jiang Zhao ${ }^{a}$ Jia $^{a} i^{a}$ \\ Xiaoyan $\mathrm{Hu}^{\mathrm{a}}$ Longkun $\mathrm{Li}^{\mathrm{a}}$
}

aDepartment of Urology, Xinqiao Hospital, Third Military Medical University, Chongqing, 'Institute of Immunology, Third Military Medical University, Chongqing, China

\section{Key Words}

Long non-coding RNAs • LncRNAs • Kidney cancer • Renal cell carcinoma • Tumorigenesis

\begin{abstract}
Renal cell carcinoma (RCC) is the most common kidney cancer diagnosed across the globe and has steadily increased in incidence in recent decades. Techniques for diagnosing or treating RCC are limited, and confined mostly to later stages of the disease. Almost all RCC pathological types are resistant to chemotherapeutics and radiation therapy. To this effect, new markers for diagnosis and target therapy are urgently needed. Advanced genome sequencing technologies have revealed long non-coding RNAs (IncRNAs) as a novel marker, transcribed throughout the human genome. The emergence of IncRNAs is an aberrant expression and is involved in the tumorigenesis of RCC. LncRNAs drive cancer phenotypes through their interaction with other cellular macromolecules including DNA, protein, and RNA. Recent research on IncRNA molecular mechanisms has revealed new markers to functionally annotate these cancers' associated transcripts, making them targets for effective diagnosis and therapeutic intervention in the fight against cancer. In this review, we first highlight the common mechanisms that underlie aberrant IncRNA expression in RCC. We go on to discuss the potential translational application of IncRNA research in the diagnosis, prognosis, and treatment of RCC.
\end{abstract}

\section{Introduction}

Cancer is a major public health problem and the leading cause of death in the world's population [1]. According to the National Central Cancer Registry of China (NCCR), the incidence of renal carcinoma (RC) ranks first among malignant tumors related to urologic cancer; the incidence of renal cell carcinoma (RCC) ranks second among malignant tumors of the urinary system, just behind bladder cancer. RRC, in short, is one of the major cancers threatening human health across the globe. There are about 63, 920 newly diagnosed cases each year [2]. Roughly one-third of RCC patients receive their diagnosis in the late phase of the

\section{$\underline{X}$. Liu and $Y$. Hao contributed equally to this work.}


disease, at which point surgical treatment is no longer feasible. Almost all RCC pathological types are resistant to chemotherapeutics and radiation therapy. Immunotherapy, at present, is the most common treatment for the late-phase disease; unfortunately, the response rate is less than $20 \%$ [3]. Better understanding of the molecular pathogenesis of RCC may reveal new opportunities for the discovery of effective cancer biomarkers and therapeutic targets.

Long non-coding RNAs (lncRNAs) have a sequence length of above 200bp and are located in nuclear or cytosolic fractions [4, 5]. An extensive landscape of functional mutations within the non-coding genome are revealed via genome-wide cancer mutation analyses, which have profound effects on the expression of long non-coding RNAs (lncRNAs). There is mounting evidence to indicate that lncRNAs can regulate gene expression at various levels, such as through chromatin modification, transcription, and post-transcription processing [6-8]. IncRNAs can drive many important cancer phenotypes by interacting with other macromolecules including DNA, protein, and RNA. Several biological processes such as transcription, translation, cellular differentiation, gene expression regulation, cell cycle, chromatin modification, and nuclear cytoplasmic trafficking can also be regulated by lncRNAs [9-11].

IncRNAs are known to play a pleotropic role in human diseases [12]. There has been a dramatic increase in research on lncRNAs in regards to tumor initiation, promotion, and progression, making them one of the hottest topics today in the field of tumor and RNA biology.

However, there has been relatively little research on the role of IncRANs in RCC specifically. A number of lncRNAs have emerged alongside studies related to the biological functions of lncRNAs in human cancers such breast cancer [13], prostate cancer [14], melanoma [15], and RCC [16]. Aberrant IncRNA expression is involved in the recurrence, metastasis, and prognosis of RCC [17-19]. The function and mechanism of IncRNAs are the most obscure and least understood elements of the extant research in terms of RCC. Better and more comprehensive understanding of lncRNAs as they affect RCC may reveal useful information on the pervasive genomic transcription in RCC tumorigenesis and metastasis. Researchers have already confirmed the importance of IncRNA biologic processes in RCC progression, and genome sequencing technologies and databases including complementary expression and other information on IncRNAs have become available to support further study [20,21].

In this review, we mainly focus on IncRNAs identified in human RCC tissues with special emphasis on those that are significantly associated with tumorigenesis and metastasis. Below, we first describe the roles and molecular mechanisms that underlie lncRNAs involved in RCC including lncRNA TUG1 [22], H19 [23], MEG3 [24], KCQN10T1 [17], MALAT1 [25], HOTAIR [26], and others. We then discuss the potential clinical application of IncRNAs in RCC diagnosis and treatment. The major challenges and future perspectives of ongoing lncRNA research related to RCC are also discussed. Finally, we propose that lncRNAs play an informative role in the initiation, promotion, and progression of RCC, thus serving as an effective biomarker of the disease.

\section{Overview of IncRNA}

\section{Origins of IncRNA}

LncRNAs were originally thought to be expression noise, which comprises the majority of the human transcripts resulting from low RNA polymerase fidelity [27]. The GENCODE annotation project established the most complete human IncRNA annotation to date, and indicated that lncRNAs are generated through pathways similar to those of protein-coding genes [28]. About 70-90\% of the human genome is pervasively transcribed and has vases that are identifiable in primary transcripts; protein-coding human genes account for less than $2 \%$ of human genome sequences $[29,30]$. There are many non-protein-coding transcripts including small inference RNAs (siRNAs), microRANs (miRNAs), PIWI-interacting RNAs (piRNAs), and long non-coding RNAs (lncRNAs) [30]. Most transcripts which are not protein- 
coding in sequence are related to lncRNAs [31]. LncRNAs are ubiquitous in all vertebrate species. Their genome sequence, rather than protein-coding genes, covers a major fraction of the human genome. These lncRNAs are located in nuclear or cytosolic fractions, may or may not be polyadenylated, and are mostly transcribed from part of either strand within a protein-coding locus [32]. LncRNA was discovered earlier than miRNA, although miRNAs have attracted more research attention over the last two decades. The first lncRNA H19 was discovered in 1990 by Brannan et al [33]. and the second lncRNA X-inactive-specific transcript (XIST) was discovered in 1991 by Brown et al. [34].

Functional long non-coding RNAs appear through various evolutionary scenarios [35]. The first scenario is the metamorphosis of the protein-coding gene into a non-coding RNA sequence. Frame disruptions are acquired by a protein-coding gene and transformed into a functional long non-coding RNA which incorporates certain previous coding sequences. The IncRNA Xist originates from the metamorphosis of a previous protein-coding gene while acquiring a transposable element sequence [36, 37]. In the second scenario, during the rearrangement of a chromosome, two well-separated untranscribed sequence regions are juxtaposed and give rise to multi-exon non-coding RNAs. Non-coding RNA (supported by ESTs BM537447, C0597044, and DN744681) in canines undergoes this lineage-specific change. The duplication of a non-coding gene by retrotransposition can also generate either a functional non-coding retrogene or a nonfunctional non-coding retropseudogene [38]. Further, neighboring repeats within a non-coding RNA can create tandem duplication events. LncRNAs may also emerge after the insertion of a transposable element, to form functional non-coding RNA $[39,40]$.

LncRNAs are more conserved than introns or random intergenic regions but less conserved than protein-coding genes [41, 42]. Evolutionary conservation is commonly used in describing the functional significance of newly discovered genes. Current researchers accept that IncRNAs are conserved in four dimensions: sequence, structure, function, and expression from syntenic loci. Two recently described knockout mouse models for the lncRNAs MALAT11 and HOTAIR highlight the multifaceted levels of conservation. These models also suggest that IncRNA sequence conservation does not always correspond to the function in other species [43].

\section{LncRNA classifications}

LncRNA classification is of fundamental importance for lncRNA research and can assist with in-depth investigations on newly discovered lncRNAs, new hypotheses based on different features of IncRNAs, and exploration of the functional mechanisms of IncRNAs [44]. Here, we summarize a few key IncRNA classifications characterized by four key features: genomic location and context, effect on DNA sequences, functioning, and targeting mechanisms.

LncRNAs can be classified into (1) sense or (2) antisense categories when overlapping one or more exons of another transcript on the same strand or opposite strand, respectively; they may also be (3) bidirectional, where a neighboring coding transcript on the opposite strand is initiated in close

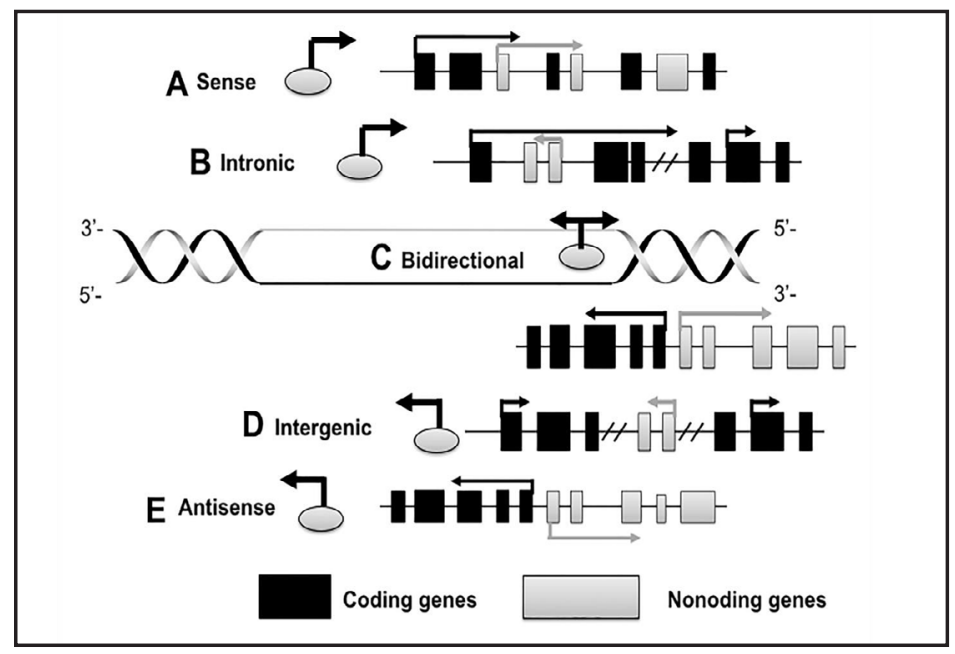

Fig. 1. Overview of five broad classifications of IncRNAs. (A) Sense; (B) Intronic; (C) Bidirectional; (D) Intergeic; (E) Antisense. 
genomic proximity to its expression, or (4) intronic, i.e., derived completely from an intron of a second transcript (although these transcript sometimes may represent pre-mRNA sequences). Finally, they may be (5) intergenic, or derived within the genomic interval between two genes (Fig. 1) [35, 44].

Other researchers have also classified lncRNAs according to their mode of action and functions [18, 45]. (1) Signal: IncRNAs may serve as molecular signaling mediators on signaling pathways to modulate a certain set of gene expressions. (2) Decoy: lncRNAs may function as molecular decoys which take proteins or RNAs away from specific locations. (3) Guide: IncRNAs can play a role as molecular guides, locating certain ribonucleoprotein complexes to a specific target site on the chromatin. (4) Scaffold: lncRNAs can support the assembly of protein complexes which link factors together in the proper complex formation to generate brand new functions.

Many studies suggest that defining lncRNAs solely on the basis of size without considering protein-coding capability is intellectually far from satisfying $[35,46]$. In the past, IncRNA was widely defined as any RNA molecule longer than 200 nucleotides that is not translated into a protein. Currently, however, IncRNAs are strictly defined as a RNA molecules which may function as primary or spliced transcripts and do not fit into small RNA or structure RNA categories (i.e., miRNAs, PIWI-interacting RNAs, transfer RNAs, spliceosomal RNAs), and with a length that is arbitrarily set (while not all lncRNAs are more than 200 nucleotides) [47]. A given IncRNA can contain ORFs longer than 100 amino acids (defined as "PCG") and not necessarily synthesize polypeptides [48]. LncRNAs are still poorly recognized overall and worthy of further study in regards to fully precise definitions.

\section{Dysregulation and molecular mechanism of IncRNAs in RCC}

In this section, we review some of the recurring molecular mechanisms that govern the manner in which lncRNAs regulate RCC tumorigenesis. LncRNA functions are consistent with IncRNA cellular localizations: nuclear lncRNAs mainly perform chromatin interactions, transcriptional regulation, and RNA processing, while cytoplasmic lncRNAs can modulate mRNA stability or translation and influence cellular signaling cascades accordingly [49]. IncRNA can drive many important cancer phenotypes through their interaction with other cellular macromolecules including DNA, protein, and RNA (Fig. 2).

LncRNAs localizing to
chromatin
LncRNA localizing
to chromatin is a well-
established mechanism
known to mediate activities
affecting neighboring
intrachromosomal genes
in cis or targeting genes
in trans on different
chromosomes [50-52].
In cis, lncRNA can recruit
protein complexes to their
site of transcription thus
creating a locus-specific
address; cells can then use
this mechanism to repress
or activate gene expression
[53]. LncRNA are commonly
known to regulate genes in

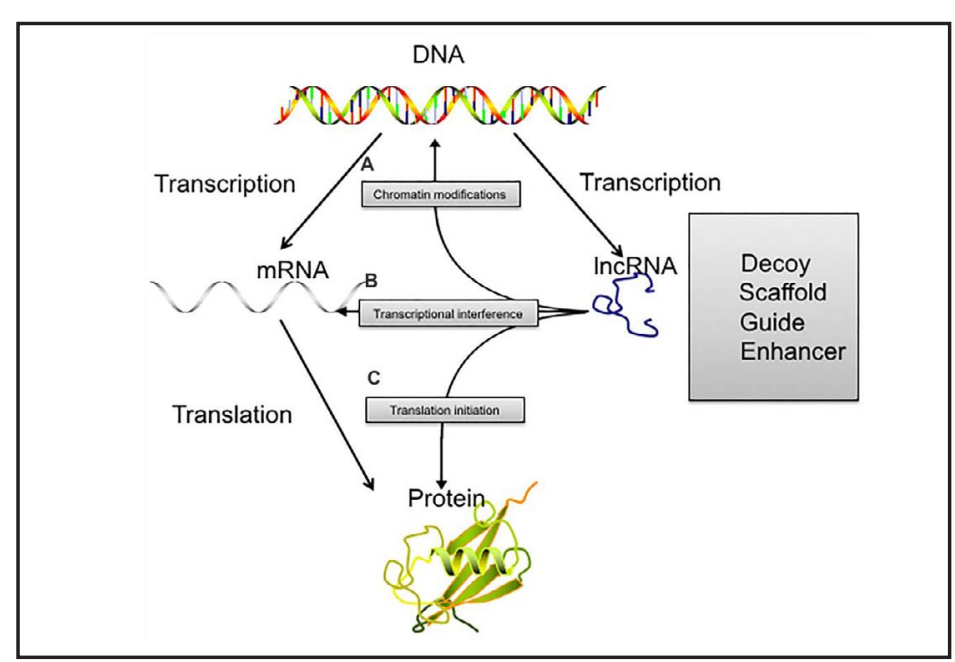

Fig. 2. IncRNA mechanisms rely on interaction with cellular macromolecules. (A) Chromatin interactions; (B) RNA interactions; (C) Protein interactions. 
cis as enhancer-associated RNAs through transcriptional regulation [54-56], transcription factor trapping [57], chromatin looping [58], and gene methylation [59]. In trans, IncRNA can recruit protein complexes to chromatin loci away from their site of transcription [60]. LncRNA are also widely known to regulate distant genes by modulating transcription factor recruitment [61] and chromatin modification [62], and by serving as a scaffold for the assembly of multiple regulatory molecules at a single locus [63].

MALAT1 (metastasis-associated lung adenocarcinoma transcript 1), also known as NEAT2 (nuclear-enriched abundant transcript 2), shows a high degree of conservativeness among several species and represents a ubiquitously expressed lncRNA [64]. A direct correlation between MALAT1 and EZH2, a subunit of PRC2, was recently established. After inactivation of MALAT1, the expression of EZH2, H3K27me3, and c-myc was observed to reduce in ccRCC in contrast to increased levels of E-cadherin. MALAT1 regulates this process in cis or trans, enabling allele-specific control of transcription. Further, MALAT1 is upregulated in ccRCC samples and in RCC cell lines compared to non-tumorous renal tissue or cells [65-67]. A knockdown of MALAT1 in RCC cell lines inhibits cell proliferation, migration, and invasion [67]. Further, the lncRNAs H19 and HOTAIR, are known to bind to PRC2 to induce gene silencing via H3K27 trimethylation in bladder cancer and breast cancer, respectively [68-70].

\section{LncRNA interactions with protein}

The interactions of IncRNAs with protein are commonly known to modulate protein function, regulate protein-protein interactions, and direct localization within cellular compartments. These interactions play key roles in determining lncRNA functional effects.

Recently, Zhai et al. identified a novel lncRNA, lncRNA ENST00000460407, which they named lncRNA-SARCC (IncRNA-Suppressing Androgen Receptor in Renal Cell Carcinoma) [71]. LncRNA-SARCC can interact with AR and decrease the stability of the AR protein. Specifically, lncRNA-SARCC suppresses AR and alters HIF-2a/c-myc signals under hypoxia. LncRNA-SARCC can be directly suppressed by HIF-2a via hypoxia responsive elements in the IncRNA promoter, forming a negative feedback loop between IncRNA-SARCC and HIF-2a that can modulate cell proliferation and migration for RCC under hypoxia.

\section{LncRNA targets RNA (RNA targets of IncRNA actions)}

LncRNA targets RNA throughout the modulation of mRNA stability, splicing, and translation. This is a newly emerging research topic in regards to the lncRNA mechanism. LncRNAs can function as molecular decoys to transport RNAs away from specific locations, as mentioned above [72]. LncRNAs have also been postulated to act as competing endogenous RNA (ceRNA) or "RNA sponges" which interact with miRNAs in a manner that can sequester these molecules and reduce their regulatory effect on target mRNA [73].

$\mathrm{Qu}$ et al. identified an lncRNA called lncARSR (nncRNA Activated in RCC with Sunitinib Resistance) [74]. LncARSR acts as a ceRNA for miR34 and miR-449 to promote AXL and c-MET expression leading to sunitinib resistance. Targeting IncARSR by LNA-based treatment restored the suinitinib responses in sunitinib-resistant RCC.

\section{LncRNAs drivers of RCC phenotypes}

Cancer consists of several phenotypes resulting from dysfunctional intrinsic cellular regulatory networks and intercellular communication which generate the tumor microenvironment $[75,76]$. Intrinsic cellular signaling networks are regulated in RCC to sustain cell proliferation, impair differentiation, enhance viability, and promote motility. As IncRNAs have been primarily studied per the role of intracellular regulatory networks in RCC, our review focuses on the role of lncRNAs in these hallmarks of cancer. Indeed, each of the hallmarks described by Hanahan and Weinberg [75] is regulated by the activity of multiple lncRNAs. 


\section{Proliferation circuits}

The HOX transcript antisense RNA (HOTAIR), an IncRNA, coordinates with chromatinmodfiying enzymes to regulate gene silencing. LncRNA HOTAIR knockdown by RNA interference with siRNA significantly affects the G0/G1 phase cell cycle and weakens RCC cell proliferation [26], which is suppressed by miR-141 in an Ago2-dependent manner [77]. LncRNA SASC2 is also downregulated by miR-21 to increase the proliferation of RCC. Hypoxia mediates tumor progression in hypoxia inducible factor-2a (HIF-2a); interestingly, lncRNA-SARCC suppresses VHL-mutant RCC cell proliferation yet promotes VHL-normal RCC proliferation by modulating androgen receptor/HIF-2a/C-MYC axis under hypoxia [71]. High levels of lncRNA CRNDE expression promotes cell proliferation by activating Wnt/bcatenin signaling [78]. LncRNA BX357664 also regulates cell proliferation via the inhibition of TGF-b1/p38/HSP27 signaling in RCC [79]. LncRNAs FTX, MALAT1, uc009by.1, and TUG1 can promote the proliferation of RCC cells, but their precise mechanisms merit further research $[22,80-82]$.

\section{Viability circuits}

lncRNAs are extensively involved in stem cell maintenance and differentiation circuits [83]. In RCC, a feed-forward loop between IncARSR and YAP activity promotes the viability of renal tumor-initiating cells [84]. Renal tumor-initiating cells contribute to tumorigenesis, and RCC progression. LncARSR attenuates the self-renewal, tumorigenicity of renal-initiating cells. Mechanistically, lncARSR binding to YAP facilitates YAP nuclear translocation, while YAP promotes IncARSR transcription.

\section{Tumor-suppressor circuits}

Several lncRNAs have been recently found to play important roles in modulating tumorsuppressor and growth-arrest pathways, such as IncRNA TRIM52-AS1, DRAIC/PCAT29, and GAS5 $[16,85,86]$. LncRNA CASC2 was downregualted in human RCC tissues and RCC cell lines (786-0 and A498), and the downrelation of lncRNA CASC2 by miR-21 also increases the proliferation and migration of RCC cells. LncRNA CADM1-AS1 regulates cell proliferation, apoptosis and migration via CADM1 modulation.

\section{Motility circuits}

The overexpression of MALAT1 and evolutionarily conserved, abundant nuclear lncRNA have been found to predict a high risk of metastatic progression in patients with RCC [87]. LncRNA MALAT1 functions as a ceRNA to regulate ZEB2 expression by sponging miR-200s in ccRCC [67]. Multiple cancer-associated IncRNAs have been implicated in regulating cancer invasion and metastasis in RCC, including lncRNA TUG1, ATB, RCCRT1, and HOTAIR [22, 88, 89].

\section{Diagnostic and therapeutic promise via IncRNAs}

LncRNAs, as highly tissue-specific drivers of cancer phenotypes, have notable potential as diagnostic markers or therapeutic targets. For instance, the high expression of MALAT1 may be a biomarker for the early detection of lymph node metastasis or a predictor of poor survival in RCC patients $[25,90]$. A 5-IncRNA signature including lncRNA-LET, PVT1, PANDAR, PTENP1, and lnc00963 can discriminate patients with clear cell RCC from healthy controls [91]. LncRNA TCL6, NBAT-1, SPRY4-IT1, RCCRT1, GAS5, and CADM1-AS1 have all been associated with poor prognosis in RCC patients [88, 92-96].

The development of RNA-targeting therapeutics represents a tremendous opportunity for modulating lncRNAs for anti-cancer therapy. Various therapeutic methods targeting lncRNAs have been developed and several pharmaceutical companies are actively developing IncRNA-targeting therapeutics $[97,98]$. Small interfering RNAs (siRNAs), upon loading in the RISC complex in the cytoplasm, can efficiently deplete lncRNAs; antisense oligonucleotides 
(ASOs) are chimeric RNA/DNA oligonucleotides that direct RNase $\mathrm{H}$ to cleave complementary target lncRNA and robustly deplete the transcripts [99]. Research has also shown that IncRNA cellular localization is critical in the screening of appropriate strategies for robust IncRNA modulation [100]. SiRNA can efficiently deplete cytoplasmic IncRNAs, while ASOs can robustly deplete IncRNAs regardless of their localization. ASOs are already currently poised for use in IncRNA-targeted therapeutics [97].

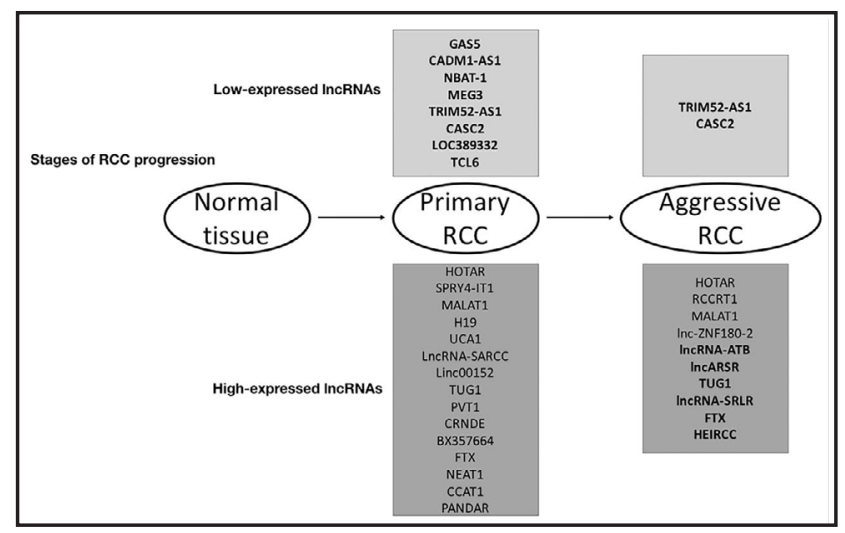

Fig. 3. Expression of lncRNAs in RCC progression.

\section{Emerging paradigms and future directions}

LncRNAs represent a new layer of complexity in the molecular architecture of human disease. The nature of protein-coding genes has been studied extensively, but the nature of non-coding genes remains a mystery. There are still many unknowns clouding our understanding of lncRNA functions, though there have been remarkable advancements in our exploration of lncRNAs and their effects on human diseases. The extant research indeed suggests that lncRNAs play a significant role in cancer diagnosis and therapy. Understanding the precise molecular mechanism of IncRNAs in hallmarks of RCC is a crucial step forward in exploring new targets for RCC therapy $[17,19,101]$.

LncRNA related to RCC is yet in its infancy, but we do now understand several important effects of lncRNAs in different states of RCC (Fig. 3). Notably, each of the hallmarks of RCC are regulated by multiple lncRNAs (Table 1). LncRNAs play an informative role in the initiation, promotion, and progression of RCC. MALAT1, for example, has been detected in the blood of RCC patients [102] and IncRNA ARSR are mediated chemotherapy-resistant in RCC [74].

There is much work yet to be done before the research discussed here can be effectively applied in the clinic, however. To facilitate this shift, it is necessary to innovate molecular tools to survey lncRNA interactions with other cellular macromolecules to identify and confirm lncRNA functions [103]. Databases centered around lncRNA information must be established and validated. We also must determine what mediates the different expressions lncRNAs in normal and cancerous tissues [104]. RCC is an immunotherapy effective disease [105], and research on whether IncRNAs can regulate the immune pathways of RCC is well merited. The epigenetic aberrations leading to variations in IncRNA expression should be carefully elucidated to determine the role of lncRNAs as drivers of tumourigenesis.

The research discussed in this review altogether indicates that IncRNAs are critical in RCC development and progression. LncRNAs may serve as effective drug targets in RCC therapy and may be better biomarkers for RCC diagnosis and prognosis than the markers

Table 1. LncRNAs in the tumorigenesis of RCC

\begin{tabular}{|c|c|c|c|c|c|}
\hline Category & LncRNA & Upstream regulators & Downstream targets & Cellular Functions & References \\
\hline \multirow[t]{8}{*}{ Primary RCC } & CADM1-AS1 & & CADM1 & Proliferation & 96 \\
\hline & MEG3 & & Bcl-2, procaspase-9 & Apoptosis & 24 \\
\hline & HOTAIR & miR-141 & JMJD3, miR-217 & Proliferation & 26,77 \\
\hline & MALAT1 & & miR-200, HIF2A & Proliferation, migration & 67 \\
\hline & & RAA-SARCC & AR, HIF2a,miR143-3p & proliferation, migration & 71 \\
\hline & PVT1 & & MYC & Proliferation & 91 \\
\hline & CRNDE & & Wnt/beta-catenin & Apoptosis & 78 \\
\hline & BX357664 & & TGF-beta1, p38 & Proliferation & 79 \\
\hline \multirow[t]{2}{*}{ Aggressive RCC } & MALAT1 & & $\mathrm{EZH} 2, \mathrm{miR}-205$ & Invasion & 66 \\
\hline & lncARSR & & miR-34, miR-449, YAP & Stem cell-like, chemoresistance & 84 \\
\hline
\end{tabular}


currently in use in clinics across the globe. Although there are interesting potential clinical targets for IncRNAs, a better and more comprehensive understanding of their functions and mechanisms in RCC pathology is yet necessary.

\section{Acknowledgements}

This work was supported by the National Natural Science Foundation of China (No. 81470989), and partly by the clinical research project key projects of the Second Affiliated Hospital, Third Military Medical University (2015YLC06). We would also like to thank Dr. Fan Yang for the constructive comments and for editing the manuscript. We are also grateful to the authors and publications that were not cited in this review due to space restrictions.

\section{Disclosure Statement}

No conflict of interests exists.

\section{References}

1 Chen W, Zheng R, Baade PD, Zhang S, Zeng H, Bray F, Jemal A, Yu XQ He J: Cancer statistics in China, 2015. CA Cancer J Clin 2016;66:115-132.

2 Rini BI, Rathmell WK, Godley P: Renal cell carcinoma. Curr Opin Oncol 2008;20:300-306.

-3 McDermott DF: Immunotherapy of metastatic renal cell carcinoma. Cancer 2009;115:2298-2305.

4 Guttman M, Rinn JL: Modular regulatory principles of large non-coding RNAs. Nature 2012;482:339-346.

5 Gutschner T, Diederichs S: The hallmarks of cancer: a long non-coding RNA point of view. RNA Biol 2012;9:703-719.

-6 Mercer TR, Dinger ME, Mattick JS: Long non-coding RNAs: insights into functions. Nat Rev Genet 2009;10:155-159.

7 Kung JT, Colognori D, Lee JT: Long noncoding RNAs: past, present, and future. Genetics 2013;193:651-669.

$>8$ Cheetham SW, Gruhl F, Mattick JS, Dinger ME: Long noncoding RNAs and the genetics of cancer. Br J Cancer 2013;108:2419-2425.

-9 Wilusz JE, Sunwoo H, Spector DL: Long noncoding RNAs: functional surprises from the RNA world. Genes Dev 2009;23:1494-1504.

10 Kim ED, Sung S: Long noncoding RNA: unveiling hidden layer of gene regulatory networks. Trends Plant Sci 2012;17:16-21.

11 Yoon JH, Abdelmohsen K, Gorospe M: Posttranscriptional gene regulation by long noncoding RNA. J Mol Biol 2013;425:3723-3730.

12 Wapinski O, Chang HY: Long noncoding RNAs and human disease. Trends Cell Biol 2011;21:354-361.

13 Yang Y, Qian J, Xiang Y, Chen Y, Qu J: The prognostic value of long noncoding RNA HOTTIP on clinical outcomes in breast cancer. Oncotarget 2016:6833-6844.

14 Ma G, Tang M, Wu Y, Xu X, Pan F, Xu R: LncRNAs and miRNAs: potential biomarkers and therapeutic targets for prostate cancer. Am J Transl Res 2016;8:5141-5150.

-15 Sun Y, Cheng H, Wang G, Yu G, Zhang D, Wang Y, Fan W, Yang W: Deregulation of miR-183 promotes melanoma development via IncRNA MALAT1 regulation and ITGB1 signal activation. Oncotarget 2017;8:3509-3518.

16 Qiao HP, Gao WS, Huo JX, Yang ZS: Long non-coding RNA GAS5 functions as a tumor suppressor in renal cell carcinoma. Asian Pac J Cancer Prev 2013;14:1077-1082.

17 Zhou S, Wang J, Zhang Z: An emerging understanding of long noncoding RNAs in kidney cancer. J Cancer Res Clin Oncol 2014;140:1989-1995.

18 Shi X, Sun M, Liu H, Yao Y, Song Y: Long non-coding RNAs: a new frontier in the study of human diseases. Cancer Lett 2013;339:159-166. 


\section{Cellular Physiology Cell Physiol Biochem 2018;47:735-746

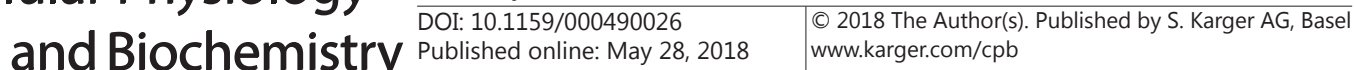

19 Martens-Uzunova ES, Bottcher R, Croce CM, Jenster G, Visakorpi T, Calin GA: Long noncoding RNA in prostate, bladder, and kidney cancer. Eur Urol 2014;65:1140-1151.

20 Dinger ME, Pang KC, Mercer TR, Crowe ML, Grimmond SM, Mattick JS: NRED: a database of long noncoding RNA expression. Nucleic Acids Res 2009;37:D122-126.

-21 Li JH, Liu S, Zhou H, Qu LH, Yang JH: starBase v2.0: decoding miRNA-ceRNA, miRNA-ncRNA and proteinRNA interaction networks from large-scale CLIP-Seq data. Nucleic Acids Res 2014;42:D92-97.

-22 Zhang M, Lu W, Huang Y, Shi J, Wu X, Zhang X, Jiang R, Cai Z, Wu S: Downregulation of the long noncoding RNA TUG1 inhibits the proliferation, migration, invasion and promotes apoptosis of renal cell carcinoma. J Mol Histol 2016;47:421-428.

23 Wang L, Cai Y, Zhao X, Jia X, Zhang J, Liu J, Zhen H, Wang T, Tang X, Liu Y, Wang J: Down-regulated long noncoding RNA H19 inhibits carcinogenesis of renal cell carcinoma. Neoplasma 2015;62:412-418.

24 Wang M, Huang T, Luo G, Huang C, Xiao XY, Wang L, Jiang GS, Zeng FQ: Long non-coding RNA MEG3 induces renal cell carcinoma cells apoptosis by activating the mitochondrial pathway. J Huazhong Univ Sci Technolog Med Sci 2015;35:541-545.

-25 Wang J, Xu AM, Zhang JY, He XM, Pan YS, Cheng G, Qin C, Hua LX, Wang ZJ: Prognostic significance of long non-coding RNA MALAT-1 in various human carcinomas: a meta-analysis. Genet Mol Res 2016;15:1-12.

26 Wu Y, Liu J, Zheng Y, You L, Kuang D, Liu T: Suppressed expression of long non-coding RNA HOTAIR inhibits proliferation and tumourigenicity of renal carcinoma cells. Tumour Biol 2014;35:11887-11894.

27 Louro R, Smirnova AS, Verjovski-Almeida S: Long intronic noncoding RNA transcription: expression noise or expression choice? Genomics 2009;93:291-298.

-28 Derrien T, Johnson R, Bussotti G, Tanzer A, Djebali S, Tilgner H, Guernec G, Martin D, Merkel A, Knowles DG, Lagarde J, Veeravalli L, Ruan X, Ruan Y, Lassmann T, Carninci P, Brown JB, Lipovich L, Gonzalez JM, Thomas M, Davis CA, Shiekhattar R, Gingeras TR, Hubbard TJ, Notredame C, Harrow J, Guigo R: The GENCODE v7 catalog of human long noncoding RNAs: analysis of their gene structure, evolution, and expression. Genome Res 2012;22:1775-1789.

29 Consortium EP, Birney E, Stamatoyannopoulos JA, Dutta A, Guigo R, Gingeras TR, Margulies EH, Weng Z, Snyder M, Dermitzakis ET, Thurman RE, Kuehn MS, Taylor CM, Neph S, Koch CM, Asthana S, Malhotra A, Adzhubei I, Greenbaum JA, Andrews RM et al.: Identification and analysis of functional elements in 1\% of the human genome by the ENCODE pilot project. Nature 2007;447:799-816.

-30 Esteller M: Non-coding RNAs in human disease. Nat Rev Genet 2011;12:861-874.

-31 Mattick JS, Makunin IV: Non-coding RNA. Hum Mol Genet 2006;15 Spec No 1:R17-29.

32 Carninci P, Kasukawa T, Katayama S, Gough J, Frith MC, Maeda N, Oyama R, Ravasi T, Lenhard B, Wells C, Kodzius R, Shimokawa K, Bajic VB, Brenner SE, Batalov S, Forrest AR, Zavolan M, Davis MJ, Wilming LG, Aidinis V, Allen JE et al.: The transcriptional landscape of the mammalian genome. Science 2005;309:15591563.

33 Brannan CI, Dees EC, Ingram RS, Tilghman SM: The product of the H19 gene may function as an RNA. Mol Cell Biol 1990;10:28-36.

-34 Brown CJ, Lafreniere RG, Powers VE, Sebastio G, Ballabio A, Pettigrew AL, Ledbetter DH, Levy E, Craig IW, Willard HF: Localization of the X inactivation centre on the human X chromosome in Xq13 Nature 1991;349:82-84.

35 Ponting CP, Oliver PL, Reik W: Evolution and functions of long noncoding RNAs. Cell 2009;136:629-641.

-36 Elisaphenko EA, Kolesnikov NN, Shevchenko AI, Rogozin IB, Nesterova TB, Brockdorff N, Zakian SM: A dual origin of the Xist gene from a protein-coding gene and a set of transposable elements. PloS One 2008;3:e2521.

37 Duret L, Chureau C, Samain S, Weissenbach J, Avner P: The Xist RNA gene evolved in eutherians by pseudogenization of a protein-coding gene. Science 2006;312:1653-1655.

-38 Hutchinson JN, Ensminger AW, Clemson CM, Lynch CR, Lawrence JB, Chess A: A screen for nuclear transcripts identifies two linked noncoding RNAs associated with SC35 splicing domains. BMC Genomics 2007;8:39.

-39 Cao X, Yeo G, Muotri AR, Kuwabara T, Gage FH: Noncoding RNAs in the mammalian central nervous system. Annu Rev Neurosci 2006;29:77-103.

40 Conley AB, Miller WJ, Jordan IK: Human cis natural antisense transcripts initiated by transposable elements. Trends Genet 2008;24:53-56. 


\section{Cellular Physiology Cell Physiol Biochem 2018;47:735-746 \begin{tabular}{l|l} 
and Biochemistry & $\begin{array}{l}\text { DOI: 10.1159/000490026 } \\
\text { Published } 2018 \text { The Author(s). Published by S. Karger AG, Basel } \\
\text { www.karger.com/cpb }\end{array}$
\end{tabular}

41 Ponjavic J, Ponting CP, Lunter G: Functionality or transcriptional noise? Evidence for selection within long noncoding RNAs. Genome Res 2007;17:556-565.

42 Yin Z, Guan D, Fan Q Su J, Zheng W, Ma W, Ke C: IncRNA expression signatures in response to enterovirus 71 infection. Biochem Biophys Res Commun 2013;430:629-633.

43 Diederichs S: The four dimensions of noncoding RNA conservation. Trends Genet 2014;30:121-123.

44 Ma L, Bajic VB, Zhang Z: On the classification of long non-coding RNAs. RNA Biol 2013;10:925-933.

45 Park JY, Lee JE, Park JB, Yoo H, Lee SH, Kim JH: Roles of Long Non-Coding RNAs on Tumorigenesis and Glioma Development. Brain Tumor Res Treat 2014;2:1-6.

-46 He Y, Meng XM, Huang C, Wu BM, Zhang L, Lv XW, Li J: Long noncoding RNAs: Novel insights into hepatocelluar carcinoma. Cancer Lett 2014;344:20-27.

47 Spizzo R, Almeida MI, Colombatti A, Calin GA: Long non-coding RNAs and cancer: a new frontier of translational research? Oncogene 2012;31:4577-4587.

-48 Washietl S, Findeiss S, Muller SA, Kalkhof S, von Bergen M, Hofacker IL, Stadler PF, Goldman N: RNAcode: robust discrimination of coding and noncoding regions in comparative sequence data. RNA 2011;17:578594.

49 Batista PJ, Chang HY: Long noncoding RNAs: cellular address codes in development and disease. Cell 2013;152:1298-1307.

50 Huarte M, Guttman M, Feldser D, Garber M, Koziol MJ, Kenzelmann-Broz D, Khalil AM, Zuk O, Amit I, Rabani M, Attardi LD, Regev A, Lander ES, Jacks T, Rinn JL: A large intergenic noncoding RNA induced by p53 mediates global gene repression in the p53 response. Cell 2010;142:409-419.

51 Huarte M: The emerging role of lncRNAs in cancer. Nat Med 2015;21:1253-1261.

-52 Sahu A, Singhal U, Chinnaiyan AM: Long noncoding RNAs in cancer: from function to translation. Trends Cancer 2015;1:93-109.

\$53 Orom UA, Derrien T, Beringer M, Gumireddy K, Gardini A, Bussotti G, Lai F, Zytnicki M, Notredame C, Huang Q Guigo R, Shiekhattar R: Long noncoding RNAs with enhancer-like function in human cells. Cell 2010;143:46-58.

54 Zhu Y, Rowley MJ, Bohmdorfer G, Wierzbicki AT: A SWI/SNF chromatin-remodeling complex acts in noncoding RNA-mediated transcriptional silencing. Mol Cell 2013;49:298-309.

55 Trimarchi T, Bilal E, Ntziachristos P, Fabbri G, Dalla-Favera R, Tsirigos A, Aifantis I: Genome-wide mapping and characterization of Notch-regulated long noncoding RNAs in acute leukemia. Cell 2014;158:593-606.

-56 Dimitrova N, Zamudio JR, Jong RM, Soukup D, Resnick R, Sarma K, Ward AJ, Raj A, Lee JT, Sharp PA, Jacks T: LincRNA-p21 activates p21 in cis to promote Polycomb target gene expression and to enforce the G1/S checkpoint. Mol Cell 2014;54:777-790.

57 Sigova AA, Abraham BJ, Ji X, Molinie B, Hannett NM, Guo YE, Jangi M, Giallourakis CC, Sharp PA, Young RA: Transcription factor trapping by RNA in gene regulatory elements. Science 2015;350:978-981.

58 Wang KC, Yang YW, Liu B, Sanyal A, Corces-Zimmerman R, Chen Y, Lajoie BR, Protacio A, Flynn RA, Gupta RA, Wysocka J, Lei M, Dekker J, Helms JA, Chang HY: A long noncoding RNA maintains active chromatin to coordinate homeotic gene expression. Nature 2011;472:120-124.

59 Schmitz KM, Mayer C, Postepska A, Grummt I: Interaction of noncoding RNA with the rDNA promoter mediates recruitment of DNMT3b and silencing of rRNA genes. Genes Dev 2010;24:2264-2269.

60 Hung T, Wang Y, Lin MF, Koegel AK, Kotake Y, Grant GD, Horlings HM, Shah N, Umbricht C, Wang P, Wang Y, Kong B, Langerod A, Borresen-Dale AL, Kim SK, van de Vijver M, Sukumar S, Whitfield ML, Kellis M, Xiong Y, Wong DJ, Chang HY: Extensive and coordinated transcription of noncoding RNAs within cell-cycle promoters. Nat Genet 2011;43:621-629.

61 Yang L, Lin C, Jin C, Yang JC, Tanasa B, Li W, Merkurjev D, Ohgi KA, Meng D, Zhang J, Evans CP, Rosenfeld MG: IncRNA-dependent mechanisms of androgen-receptor-regulated gene activation programs. Nature 2013;500:598-602.

62 Wang KC, Chang HY: Molecular mechanisms of long noncoding RNAs. Mol Cell 2011;43:904-914.

63 Tsai MC, Manor O, Wan Y, Mosammaparast N, Wang JK, Lan F, Shi Y, Segal E, Chang HY: Long noncoding RNA as modular scaffold of histone modification complexes. Science 2010;329:689-693.

64 Ji P, Diederichs S, Wang W, Boing S, Metzger R, Schneider PM, Tidow N, Brandt B, Buerger H, Bulk E, Thomas M, Berdel WE, Serve H, Muller-Tidow C: MALAT-1, a novel noncoding RNA, and thymosin beta4 predict metastasis and survival in early-stage non-small cell lung cancer. Oncogene 2003;22:8031-8041.

65 Zhang HM, Yang FQ, Chen SJ, Che J, Zheng JH: Upregulation of long non-coding RNA MALAT1 correlates 


\section{Cellular Physiology Cell Physiol Biochem 2018;47:735-746

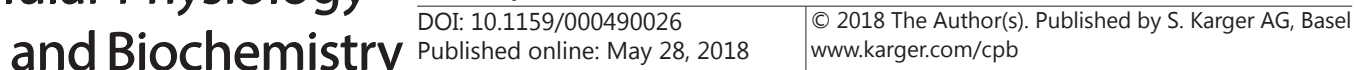

Liu et al.: LncRNA Emergence During RCC Tumorigeniesis

with tumor progression and poor prognosis in clear cell renal cell carcinoma. Tumour Biol 2015;36:29472955.

66 Hirata H, Hinoda Y, Shahryari V, Deng G, Nakajima K, Tabatabai ZL, Ishii N, Dahiya R: Long Noncoding RNA MALAT1 Promotes Aggressive Renal Cell Carcinoma through Ezh2 and Interacts with miR-205 Cancer Res 2015;75:1322-1331.

67 Xiao H, Tang K, Liu P, Chen K, Hu J, Zeng J, Xiao W, Yu G, Yao W, Zhou H, Li H, Pan Y, Li A, Ye Z, Wang J, Xu $\mathrm{H}$, Huang Q: LncRNA MALAT1 functions as a competing endogenous RNA to regulate ZEB2 expression by sponging miR-200s in clear cell kidney carcinoma. Oncotarget 2015;6:38005-38015.

-68 Benetatos L, Voulgaris E, Vartholomatos G, Hatzimichael E: Non-coding RNAs and EZH2 interactions in cancer: long and short tales from the transcriptome. Int J Cancer 2013;133:267-274.

69 Yoo KH, Hennighausen L: EZH2 methyltransferase and H3K27 methylation in breast cancer. Int J Biol Sci 2012;8:59-65.

70 Luo M, Li Z, Wang W, Zeng Y, Liu Z, Qiu J: Long non-coding RNA H19 increases bladder cancer metastasis by associating with EZH2 and inhibiting E-cadherin expression. Cancer Lett 2013;333:213-221.

71 Zhai W, Sun Y, Jiang M, Wang M, Gasiewicz TA, Zheng J, Chang C: Differential regulation of LncRNA-SARCC suppresses VHL-mutant RCC cell proliferation yet promotes VHL-normal RCC cell proliferation via modulating androgen receptor/HIF-2alpha/C-MYC axis under hypoxia. Oncogene 2016;35:4866-4880.

72 Gong C, Maquat LE: IncRNAs transactivate STAU1-mediated mRNA decay by duplexing with 3' UTRs via Alu elements. Nature 2011;470:284-288.

73 Tay Y, Rinn J, Pandolfi PP: The multilayered complexity of ceRNA crosstalk and competition. Nature 2014;505:344-352.

-74 Qu L, Ding J, Chen C, Wu ZJ, Liu B, Gao Y, Chen W, Liu F, Sun W, Li XF, Wang X, Wang Y, Xu ZY, Gao L, Yang Q, Xu B, Li YM, Fang ZY, Xu ZP, Bao Y, Wu DS, Miao X, Sun HY, Sun YH, Wang HY, Wang LH: ExosomeTransmitted lncARSR Promotes Sunitinib Resistance in Renal Cancer by Acting as a Competing Endogenous RNA. Cancer Cell 2016;29:653-668.

75 Hanahan D, Weinberg RA: The hallmarks of cancer. Cell 2000;100:57-70. Hanahan D, Weinberg RA: Hallmarks of cancer: the next generation. Cell 2011;144:646-674. Chiyomaru T, Fukuhara S, Saini S, Majid S, Deng G, Shahryari V, Chang I, Tanaka Y, Enokida H, Nakagawa M, Dahiya R, Yamamura S: Long non-coding RNA HOTAIR is targeted and regulated by miR-141 in human cancer cells. J Biol Chem 2014;289:12550-12565.

78 Shao K, Shi T, Yang Y, Wang X, Xu D, Zhou P: Highly expressed lncRNA CRNDE promotes cell proliferation through Wnt/beta-catenin signaling in renal cell carcinoma. Tumour Biol 2016:1-8.

-79 Liu Y, Qian J, Li X, Chen W, Xu A, Zhao K, Hua Y, Huang Z, Zhang J, Liang C, Su S, Li P, Shao P, Li J, Qin C, Wang Z: Long noncoding RNA BX357664 regulates cell proliferation and epithelial-to-mesenchymal transition via inhibition of TGF-beta1/p38/HSP27 signaling in renal cell carcinoma. Oncotarget 2016;7:81410-81422.

80 Chen S, Ma P, Zhao Y, Li B, Jiang S, Xiong H, Wang Z, Wang H, Jin X, Liu C: Biological function and mechanism of MALAT-1 in renal cell carcinoma proliferation and apoptosis: role of the MALAT-1-Livin protein interaction. J Physiol Sci 2016:1-9.

-81 He X, Sun G, Guo F, Wang K, Gao Y, Feng Y, Song B, Li W, Li Y: Knockdown of long non-coding RNA FTX inhibits proliferation, migration, and invasion in renal cell carcinoma cells. Oncol Res 2016

82 Ren X, Lan T, Chen Y, Shao Z, Yang C, Peng J: lncRNA uc009yby.1 promotes renal cell proliferation and is associated with poor survival in patients with clear cell renal cell carcinomas. Oncol Lett 2016;12:19291934.

83 Flynn RA, Chang HY: Long noncoding RNAs in cell-fate programming and reprogramming. Cell Stem Cell 2014;14:752-761.

-84 Qu L, Wu Z, Li Y, Xu Z, Liu B, Liu F, Bao Y, Wu D, Liu J, Wang A, Chu X, Sun Y, Chen C, Zhang Z, Wang L: A feedforward loop between lncARSR and YAP activity promotes expansion of renal tumour-initiating cells. Nat Commun 2016;7:12692.

85 Liu Z, Yan HY, Xia SY, Zhang C, Xiu YC: Downregulation of long non-coding RNA TRIM52-AS1 functions as a tumor suppressor in renal cell carcinoma. Mol Med Rep 2016;13:3206-3212.

86 Sakurai K, Reon BJ, Anaya J, Dutta A: The lncRNA DRAIC/PCAT29 Locus Constitutes a Tumor-Suppressive Nexus. Mol Cancer Res 2015;13:828-838.

-87 Zhu L, Liu J, Ma S, Zhang S: Long Noncoding RNA MALAT-1 Can Predict Metastasis and a Poor Prognosis: a Meta-Analysis. Pathol Oncol Res 2015;21:1259-1264. 


\section{Cellular Physiology Cell Physiol Biochem 2018;47:735-746

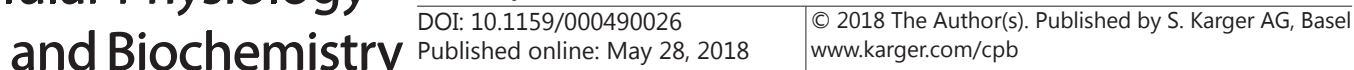

Liu et al.: LncRNA Emergence During RCC Tumorigeniesis

88 Song S, Wu Z, Wang C, Liu B, Ye X, Chen J, Yang Q, Ye H, Xu B, Wang L: RCCRT1 is correlated with prognosis and promotes cell migration and invasion in renal cell carcinoma. Urology 2014;84:730.e731-737.

89 Xiong J, Liu Y, Jiang L, Zeng Y, Tang W: High expression of long non-coding RNA IncRNA-ATB is correlated with metastases and promotes cell migration and invasion in renal cell carcinoma. Jpn J Clin Oncol 2016;46:378-384.

90 Chen J, Chen Y, Gu L, Li X, Gao Y, Lyu X, Chen L, Luo G, Wang L, Xie Y, Duan J, Peng C, Ma X: LncRNAs act as prognostic and diagnostic biomarkers in renal cell carcinoma: a systematic review and meta-analysis. Oncotarget 2016;7:74325-74336.

-91 Wu Y, Wang YQ, Weng WW, Zhang QY, Yang XQ, Gan HL, Yang YS, Zhang PP, Sun MH, Xu MD, Wang CF: A serum-circulating long noncoding RNA signature can discriminate between patients with clear cell renal cell carcinoma and healthy controls. Oncogenesis 2016;5:e192.

$\$ 2$ Su H, Sun T, Wang H, Shi G, Zhang H, Sun F, Ye D: Decreased TCL6 expression is associated with poor prognosis in patients with clear cell renal cell carcinoma. Oncotarget 2017;8:5789-5799.

-93 Xue S, Li QW, Che JP, Guo Y, Yang FQ, Zheng JH: Decreased expression of long non-coding RNA NBAT-1 is associated with poor prognosis in patients with clear cell renal cell carcinoma. Int J Clin Exp Pathol 2015;8:3765-3774.

-94 Zhang HM, Yang FQ, Yan Y, Che JP, Zheng JH: High expression of long non-coding RNA SPRY4-IT1 predicts poor prognosis of clear cell renal cell carcinoma. International J Clin Exp Pathol 2014;7:5801-5809.

$\$ 95$ Tu ZQ, Li RJ, Mei JZ, Li XH: Down-regulation of long non-coding RNA GAS5 is associated with the prognosis of hepatocellular carcinoma. J Clin Exp Pathol 2014;7:4303-4309.

-96 Yao J, Chen Y, Wang Y, Liu S, Yuan X, Pan F, Geng P: Decreased expression of a novel lncRNA CADM1-AS1 is associated with poor prognosis in patients with clear cell renal cell carcinomas. International J Clin Exp Pathol 2014;7:2758-2767.

-97 Ling H, Fabbri M, Calin GA: MicroRNAs and other non-coding RNAs as targets for anticancer drug development. Nat Rev Drug Discov 2013;12:847-865.

$\$ 98$ Li CH, Chen Y: Targeting long non-coding RNAs in cancers: progress and prospects. Int J Biochem Cell Biol 2013;45:1895-1910.

99 Ideue T, Hino K, Kitao S, Yokoi T, Hirose T: Efficient oligonucleotide-mediated degradation of nuclear noncoding RNAs in mammalian cultured cells. RNA 2009;15:1578-1587.

100 Lennox KA, Behlke MA: Cellular localization of long non-coding RNAs affects silencing by RNAi more than by antisense oligonucleotides. Nucleic Acids Res 2016;44:863-877.

101 Seles M, Hutterer GC, Kiesslich T, Pummer K, Berindan-Neagoe I, Perakis S, Schwarzenbacher D, Stotz M, Gerger A, Pichler M: Current Insights into Long Non-Coding RNAs in Renal Cell Carcinoma. Int J Mol Cell Med 2016;17:573.

102 Kohls K, Schmidt D, Holdenrieder S, Muller SC, Ellinger J: Detection of cell-free lncRNA in serum of cancer patients. Urologe A 2015;54:819-825.

103 Chu C, Spitale RC, Chang HY: Technologies to probe functions and mechanisms of long noncoding RNAs. Nat Struct Mol Biol 2015;22:29-35.

104 Calin GA, Liu CG, Ferracin M, Hyslop T, Spizzo R, Sevignani C, Fabbri M, Cimmino A, Lee EJ, Wojcik SE, Shimizu M, Tili E, Rossi S, Taccioli C, Pichiorri F, Liu X, Zupo S, Herlea V, Gramantieri L, Lanza G, Alder H, Rassenti L, Volinia S, Schmittgen TD, Kipps TJ, Negrini M, Croce CM: Ultraconserved regions encoding ncRNAs are altered in human leukemias and carcinomas. Cancer Cell 2007;12:215-229.

105 Mendiratta P, Rini BI, Ornstein MC: Emerging immunotherapy in advanced renal cell carcinoma. Urol Oncol 2017;35:687-693. 